\title{
Pengembangan modul matematika dengan model pembelajaran berbasis masalah untuk siswa kelas VII SMP
}

\author{
Anjas Setyadi ${ }^{1}$, Abdul Aziz Saefudin ${ }^{{ }^{*}}$ \\ ${ }^{1}$ Program Studi Pendidikan Matematika, Universitas PGRI Yogyakarta, Indonesia \\ *Corresponding Author. E-mail: aziz@upy.ac.id
}

\begin{tabular}{ll}
\hline \multicolumn{1}{c}{ ARTICLE INFO } & \multicolumn{1}{c}{ ABSTRACT } \\
\hline Article History: & Penelitian ini bertujuan untuk mendeskripsikan proses pengembangan dan mengasilkan \\
Received: 7 Nov. 2018 & modul matematika dengan model pembelajaran berbasis masalah untuk siswa kelas VII SMP \\
Revised: 25 May 2019 & pada materi segiempat, serta mendeskripsikan kualitas modul matematika ditinjau dari kuali- \\
Accepted: 20 June 2019 & tas kevalidan, kepraktisan, dan keefektifan. Penelitian ini merupakan penelitian pengem- \\
& bangan yang mengacu pada model pengembangan ADDIE dengan tahapan Analysis, Design, \\
& Development, Implementation, dan Evaluation. Subjek uji coba penelitian adalah siswa kelas VII \\
Keywords: & A SMP Negeri 2 Pajangan, Bantul. Teknik pengumpulan data yang digunakan dalam penelitian \\
Pengembangan & ini berupa observasi, angket, dan tes. Observasi dilakukan untuk mengamati keterlaksanaan \\
Modul matematika & pembelajaran. Angket digunakan untuk mengetahui penilaian ahli dan respon siswa, sedang- \\
Pembelajaran berbasis & kan soal tes digunakan untukmengetahui hasil belajar siswa setelah menggunakan modul yang \\
masalah & dikembangkan. Hasil penelitian menunjukkan bahwa (1) kevalidan modul berdasarkan rata- \\
Segiempat & rata penilaian dosen ahli materi adalah 3,36 termasuk kriteria baik dan rata-rata penilaian guru \\
Development & ahli materi adalah 2,88 termasuk kriteria baik, sedangkan berdasarkan rata-rata penilaian ahli \\
Mathematics module & media adalah 3,08 termasuk kriteria baik; (2) kepraktisan modul berdasarkan rata-rata hasil \\
Problem-based learning & respon siswa adalah 3,12 termasuk kriteria baik dan rata-rata persentase hasil observasi keter- \\
Rectangular & laksanaan pembelajaran adalah 89,78\% termasuk kriteria sangat baik; (3) keefektifan modul \\
& berdasarkan tes hasil belajar siswa dengan persentase ketuntasan mencapai KKM adalah \\
& 73,33\% termasuk kriteria baik. \\
\cline { 2 - 3 }
\end{tabular}

This research aimed to describe the process of development and to produce mathematics module with problem-based learning model for 7 th grade of junior high school students in rectangular material and describe the quality of the mathematics module in terms of the quality of validity, practicality, and effectiveness. This research was development research that referred to the model of ADDIE development with the stages of Analysis, Design, Development, Implementation, and Evaluation. The subject of the research involved the students of the 7th grade ofSMP Negeri 2 Pajangan, Bantul, Indonesia. The data collection technique used in this research was observation, questionnaire, and test. The observation was used to observing the implementation of learning. The questionnaire was used to know the expert assessment results and student response, while the test questions were used to asses student learning outcomes after using the module. The results showed that (1) validity of module based on the average assessment material experts was 3,36 including good criteria and the average assessment of teachers was 2,88 including good criteria, while based on the average assessment of media experts was 3,08 including good criteria; (2) practicality of module based on the average of student response result was 3,12 including good criteria and average of percentage observation result of learning activity was $89,78 \%$ including very good criteria; (3) effectiveness of module based on the test student learning outcomes with the percentage of completeness reached the Minimum ComScan me pleteness Criteria was $73.33 \%$ including good criteria.

This is an open access article under the CC-BY-SA license

\section{How to Cite:}

Setyadi, A., \& Saefudin, A. A. (2019). Pengembangan modul matematika dengan model pembelajaran berbasis masalah untuk siswa kelas VII SMP. Pythagoras: Jurnal Pendidikan Matematika, 14(1), 12-22. doi: https://doi.org/10.21831/pg.v14i1.16771 


\section{PENDAHULUAN}

Matematika sangat berguna untuk kehidupan sehari-hari. Matematika merupakan mata pelajaran yang ada dalam satuan pendidikan formal, mulai dari sekolah dasar sampai perguruan tinggi. Pendidikan formal merupakan pendidikan di sekolah yang diperoleh secara teratur dan sistematis. Sekolah merupakan tempat terjadinya interaksi antara guru dan siswa dalam proses pembelajaran, sehingga proses pembelajaran harus dilaksanakan dengan sebaik-baiknya. Matematika mengajarkan siswa untuk terampil berpikir kritis (Apino \& Retnawati, 2017; Firdaus \& Bakry, 2015; Sanders, 2016) dan mampu memecahkan suatu permasalahan (Csíkos, Szitányi, \& Kelemen, 2011; NCTM, 2000; Özreçberoğlu \& Çağanağa, 2017) baik dalam bidang matematika maupun dalam bidang lain yang ada dalam kehidupan sehari-hari. Oleh karena itu, pelajaran matematika di berbagai jenjang pendidikan formal perlu mendapatkan perhatian yang sungguh-sungguh terutama dalam proses pembelajarannya.

Salah satu unsur penting dalam proses pembelajaran pada pendidikan formal yaitu seorang guru (Pajares, 1992; Tłuściak-Deliowska, 2017). Guru merupakan subjek yang merencanakan dan mengatur semua proses terjadinya pembelajaran di kelas. Ketika guru dapat membuat suatu perencanaan pembelajaran yang baik, maka tujuan pembelajaran yang diharapkan dapat tercapai. Untuk membuat perencanaan pembelajaran, diperlukan pemilihan model atau pendekatan pembelajaran yang sesuai dengan karakteristik siswa (Rhosyida \& Jailani, 2014; Sulistyani \& Retnawati, 2015), sehingga pembelajaran menjadi efektif.

Fakta di lapangan masih menunjukkan bahwa dalam proses pembelajaran belum sesuai dengan apa yang diharapkan. Beberapa hasil penelitian (misalnya: Fitrianawati \& Hartono, 2016; Sulistyani \& Retnawati, 2015; Trisnadati, 2018) melaporkan bahwa beberapa guru masih mengajar menggunakan pembelajaran konvensional, sehingga proses pembelajaran di kelas hanya terjadi satu arah yang menyebabkan siswa menjadi pasif. Model pembelajaran konvensional berpusat pada guru dan menghalangi keterlibatan siswa dalam proses pembelajaran di kelas. Siswa hanya menulis apa yang dituliskan guru pada papan tulis dan menulis contoh soal yang guru berikan. Jika diberikan soal latihan dengan tipe berbeda maka siswa kesulitan dalam menyelesaikannya. Selain pemilihan model pembelajaran yang sesuai, dalam perencanaan pembelajaran juga dibutuhkan sarana penunjang seperti bahan ajar yang dapat memenuhi kebutuhan belajar siswa.

Berdasarkan hasil pengamatan dan wawancara dengan guru matematika kelas VII di salah satu SMP di Kabupaten Bantul, Daerah Istimewa Yogyakarta, didapat informasi bahwa guru belum mengembangkan bahan ajar sendiri. Ketika proses pembelajaran di dalam kelas guru hanya menggunakan buku paket dan buku Lembar Kegiatan Siswa (LKS). Kondisi ini jelas menunjukkan bahwa bahan ajar yang dimiliki oleh guru di sekolah tersebut masih belum memadai. Hal tersebut sesuai dengan temuan beberapa peneliti lainnya (misalnya Gazali, 2016; Pangesti \& Retnowati, 2017), yang memperkuat adanya indikasi bahwa bahan ajar yang dimiliki oleh guru matematika saat ini kurang relevan dengan kebutuhan belajar siswa saat ini.

Salah satu yang mempengaruhi kegiatan proses pembelajaran adalah tersedianya bahan ajar yang memadai. Dengan demikian diharapkan agar guru sebagai pelaksana pembelajaran dapat mengembangkan bahan ajar yang sesuai dengan karakterisktik siswa sebagai salah satu variasi bahan ajar. Adanya bahan ajar yang dibuat sendiri oleh guru akan sangat mempermudah guru dalam melaksanakan proses pembelajaran di kelas, sehingga tujuan pembelajaran dapat tercapai dengan efektif. Selain itu, bahan ajar yang dibuat juga harus disesuaikan dengan karakteristik materi ajar, terutama untuk materi-materi yang dianggap sulit oleh siswa.

Salah satu materi yang diajarkan di kelas VII adalah segiempat. Pada kenyataannya siswa masih mengalami kesulitan dalam memahami konsep materi segiempat dan masih banyak hasil belajar siswa yang belum mencapai Kriteria Ketuntasan Minimal (KKM). Berdasarkan informasi yang diperoleh dari salah satu SMP di Kabupaten Bantul, Daerah Istimewa Yogyakarta, bahwa sekolah tersebut mematok nilai KKM yaitu 71 untuk kelas VII. Berdasarkan hasil nilai ulangan harian pada materi segiempat, persentase ketuntasan siswa hanya $37,5 \%$. Hal ini menunjukkan bahwa belum efektifnya pembelajaran yang dilakukan, sehingga persentase ketuntasan siswa dalam mencapai nilai KKM masih rendah. Rendahnya ketuntasan hasil belajar siswa tersebut dapat disebabkan karena dalam proses belajar mengajar masih didominasi dengan model pembelajaran konvensional, sehingga siswa akan cenderung pasif. Berkaca pada kondisi tersebut, maka diperlukan kesadaran tinggi dari siswa untuk belajar secara mandiri serta didukung dengan tersedianya bahan ajar yang dapat meningkatkan minat belajar siswa. Hal ini menunjukkan bahwa guru harus menggunakan bahan ajar yang bervariasi dan disesuaikan dengan kondisi siswa sehingga pembelajaran menjadi lebih bermakna bagi siswa. Dengan demikian, perlu dikembangkan suatu bahan ajar yang dapat memfasilitasi proses belajar siswa secara aktif. 
Salah satu bahan ajar yang dapat dikembangkan oleh guru yaitu modul. Modul adalah sebuah buku yang ditulis dengan tujuan agar peserta didik dapat belajar secara mandiri tanpa atau dengan bimbingan guru (Depdiknas, 2008, p.13). Penyajian materi pada modul tersusun sistematis dan lengkap yang memudahkan untuk belajar mandiri dan mengatur waktu belajar siswa. Modul merupakan jenis kesatuan kegiatan belajar yang terencana, dirancang untuk membantu para peserta didik secara individual dalam mencapai tujuan-tujuan belajarnya (Sukiman, 2012, p.131). Pada bahan ajar berupa modul terdapat umpan balik dan tindak lanjut yang harus dilakukan siswa setelah mempelajari modul. Dengan demikian siswa dapat mengukur sendiri tingkat penguasaan materi yang dipelajari.

Pembelajaran menggunakan modul juga dapat memberikan kesempatan bagi siswa untuk membangun pengetahuannya sendiri. Dalam hal ini, melalui penggunaan modul siswa dapat diarahkan untuk memusatkan perhatiannya pada masalah dan mencari alternatif-alternatif pemecahannya, baik secara individu maupun dalam kelompok. Dengan demikian modul akan efektif jika dipadukan dengan pembelajaran berbasis masalah. Pembelajaran berbasis masalah merupakan proses pembelajaran yang melibatkan siswa dalam penyelidikan pilihan sendiri yang memungkinkan mereka menginterprestasikan dan menjelaskan fenomena dunia nyata dan membangun pemahaman tentang fenomena itu (Rusman, 2014, p.243). Masalah yang diajukan berkaitan dengan kehidupan sehari-hari siswa sehingga siswa merasa tertarik untuk menyelesaikannya.

Arends $(2007$, p.380) menyatakan bahwa inti dari pembelajaran berbasis masalah terdiri dari menyajikan siswa dengan situasi otentik dan bermakna yang dapat berfungsi sebagai loncatan untuk penyelidikan dan penemuan. Pembelajaran berbasis masalah menempatkan siswa untuk aktif dalam proses pembelajaran dan kebebasan dalam mengembangkan kreativitas dalam belajar. Pembelajaran berbasis masalah juga dapat digunakan untuk melatihkan kemampuan berpikir tingkat tinggi dan karakter siswa (Jailani, Sugiman, \& Apino, 2017), melatihkan kemampuan berpikir kritis (Hmelo-Silver, 2004; Sungur \& Tekkaya, 2006), serta meningkatkan pemahaman mendalam siswa dan kapasitasnya dalam menerapkan konsep-konsep yang telah mereka pelajari. Secara operasional, langkah pembelajaran berbasis masalah meliputi mengorientasi siswa pada masalah, mengorganisasi siswa untuk belajar, memandu siswa untuk melakukan investigasi baik secara individu maupun kelompok, mengembangkan dan menyajikan prosedur pemecahan masalah, dan menganalisis dan mengevaluasi proses pemecahan masalah (Arends, 2007). Dengan demikian pembelajaran berbasis masalah dapat dijadikan sebagai solusi untuk mengatasi kesulitan belajar siswa.

Berdasarkan uraian masalah dan kajian teori yang telah dikemukakan sebelumnya, pengembangan bahan ajar berupa modul perlu dilakukan untuk membantu siswa meningkatkan prestasi belajarnya. Namun isi dari modul tersebut juga harus sejalan dengan prinsip pembelajaran bermakna serta mampu memfasilitasi siswa untuk terlibat aktif dalam pembelajaran. Dengan demikian modul pembelajaran dengan pembelajaran berbasis masalah dapat dijadikan sebagai alternatif untuk mengatasi permasalah yang telah dikemukakan sebelumnya. Oleh karena itu tujuan dari penelitian ini adalah untuk mendeskripsikan proses pengembangan dan menghasilkan modul matematika dengan model pembelajaran berbasis masalah untuk siswa kelas VII SMP pada materi segiempat, serta untuk mengetahui kualitas modul tersebut ditinjau dari kualitas kevalidan, kepraktisan dan keefektifan.

\section{METODE}

Penelitian ini termasuk dalam jenis penelitian pengembangan (Research and Development). Menurut Sugiyono $(2015$, p.30) metode penelitian dan pengembangan dapat diartikan sebagai cara ilmiah untuk meneliti, merancang, memproduksi dan menguji kualitas produk yang dihasilkan. Produk yang dikembangkan berupa modul matematika dengan model pembelajaran berbasis masalah pada materi segiempat. Penilaian kualitas modul yang dikembangkan menggunakan penilaian menurut kriteria Nieveen. Menurut Nieveen (Rochmad, 2012, p.64) kriteria kualitas pengembangan bahan ajar meliputi kevalidan (validity), kepraktisan (practicality), dan keefektifan (effectiveness).

Penelitian ini dilaksanakan di SMP Negeri 2 Pajangan, Bantul, Daerah Istimewa Yogyakarta. Subjek uji coba dalam penelitian ini adalah siswa kelas VII A yang terdiri dari 32 siswa. Uji coba bahan ajar berupa modul dilaksanakan sebayak 5 kali pertemuan, yaitu pada tanggal 15 Mei 2017 sampai dengan 24 Mei 2017, dengan rincian 4 kali pertemuan untuk kegiatan pembelajaran dan 1 kali pertemuan untuk tes dan pengisian angket respon siswa. 


\section{Prosedur}

Model penelitian dan pengembangan yang digunakan dalam penelitian ini adalah model pengembangan ADDIE. Mulyatiningsih (2012, p.178) menyatakan bahwa model ADDIE merupakan singkatan dari Analysis (analisis), Design (desain), Development (pengembangan), Implementation (implementasi) dan Evaluation (evaluasi) yang dikembangkan oleh Dick and Carry. Pada tahap analisis peneliti melakukan analisis kebutuhan, analisis kurikulum dan, analisis karakteristik siswa. Analisis kebutuhan dilakukan dengan menganalisis potensi dan masalah yang dijadikan sebagai dasar pengembangan modul. Analisis kurikulum dilakukan dengan menganalisis kompetensi dasar untuk memahami kedalaman dan keluasan materi. Analisis karakteristik siswa dilakukan dengan observasi ketika siswa sedang melakukan proses pembelajaran dan mencari informasi mengenai siswa secara khusus dengan diskusi dengan guru.

Tahap desain yaitu menyusun draft bahan ajar berbentuk modul, penyusunan garis besar penyajian materi, pengumpulan referensi, dan penyusunan instrumen-instrumen penelitian. Instrumen disusun dengan memperhatikan aspek kelayakan isi, aspek penyajian, aspek bahasa, aspek tampilan dan kesesuaian dengan karakteristik pembelajaran berbasis masalah. Instrumen yang disusun berupa lembar angket dan tes hasi belajar. Lembar angket untuk ahli materi, ahli media, dan angket respon siswa. Tes hasil belajar digunakan untuk mengukur tingkat pemahaman siswa setelah pembelajaran menggunakan modul yang dikembangkan.

Tahap pengembangan yaitu melanjutkan perihal yang telah disusun pada tahap desain, meliputi penyusunan secara menyeluruh materi, serta merancang materi yang disesuaikan dengan model pembelajaran berbasis masalah. Modul yang telah dikembangkan kemudian dikonsultasikan dengan dosen pembimbing untuk kemudian divalidasi oleh validator ahli materi dan ahli media. Validasi dilakukan untuk mengetahui kelayakan modul yang dikembangkan dan masukan-masukan dari ahli materi dan ahli media dijadikan sebagai dasar perbaikan modul sebelum diujicobakan.

Tahap implementasi dilakukan dengan melaksanakan pembelajaran di kelas dengan modul yang telah dikembangkan. Saat melakukan uji coba, peneliti yang bertindak sebagai pengajar mengajak observer untuk mengamati kegiatan pembelajaran. Pada akhir pertemuan siswa mengisi angket respon siswa dan mengerjakan tes hasil belajar untuk mengetahui tingkat pemahaman siswa setelah mengikuti pembelajaran menggunakan modul yang dikembangkan.

Tahap akhir yaitu evaluasi, dimana pada tahap evaluasi ini dilakukan analisis data hasil angket respon siswa, analisis hasil observasi keterlaksanaan pembelajaran, dan analisis nilai tes hasil belajar. Hasil analisis dari angket respon siswa dan observasi keterlaksanaan pembelajaran digunakan untuk mengetahui kepraktisan modul, sedangkan data nilai tes hasil belajar digunakan untuk mengetahui keefektifan modul.

\section{Teknik Pengumpulan Data dan Instrumen Penelitian}

Pada penelitian ini teknik pengumpulan data berupa observasi, angket, dan tes. Instrumen pada penelitian ini digunakan sebagai alat penilaian untuk mendapatkan data tentang kevalidan, kepraktisan dan keefektifan modul yang dikembangkan. Instrumen untuk mengukur kevalidan menggunakan lembar angket penilaian ahli materi dan ahli media. Angket penilaian ahli materi dan ahli media menggunakan 4 alternatif jawaban yaitu Sangat Kurang (SK), Kurang (K), Baik (B), dan Sangat Baik (SB). Instrumen untuk mengukur kepraktisan menggunakan lembar angket respon siswa dan lembar observasi keterlaksanaan pembelajaran. Angket respon siswa menggunakan 4 alternatif jawaban yaitu Sangat Setuju (SS), Setuju (S), Tidak Setuju (TS), dan Sangat Tidak Setuju (STS). Lembar observasi digunakan untuk mengamati keterlaksanaan kegiatan guru dan siswa. Lembar observasi keterlaksanaan menggunakan 2 alternatif jawaban yaitu "Ya" dan "Tidak". Instrumen untuk mengukur keefektifan menggunakan soal tes hasil belajar yang terdiri dari 6 butir soal uraian. Tes hasil belajar dilakukan setelah pembelajaran menggunakan modul yang dikembangkan.

\section{Teknik Analisis Data}

Analisis data dilakukan untuk menilai kriteria kualitas modul berdasarkan aspek kevalidan, kepraktisan, dan keefektifan. Data yang diperoleh dari lembar angket penilaian ahli materi, angket penilaian ahli media, lembar angket respon siswa, dan hasil tes dianalisis dengan menghitung skor rata-rata dari masing-masing instrumen, kemudian mengkonversinya menjadi data kualitatif dengan acuan rumus menurut Widoyoko $(2009$, p.238), sebagaimana disajikan pada Tabel 1. 
Tabel 1. Konversi Data Hasil Penilaian

\begin{tabular}{ll}
\hline Rentang Skor & Kriteria \\
\hline$X>M i+1,80 S B I$ & Sangat Baik \\
$M i+0,60 S B I<X \leq M i+1,80 S B I$ & Baik \\
$M i-0,60 S B I<X \leq M i+0,60 S B I$ & Cukup \\
$M i-1,80 S B I<X \leq M i-0,60 S B I$ & Kurang \\
$X \leq \overline{M \imath}-1,80 S B I$ & Sangat Kurang \\
\hline
\end{tabular}

Keterangan:

$X \quad=$ skor empiris

$M i=$ rata-rata ideal

$M i=\frac{1}{2} \times($ skor maksimal ideal + skor minimal ideal $)$

$S B I=$ simpangan baku ideal

$S B I=\frac{1}{6} \times($ skor maksimal ideal - skor minimal ideal)

Analisis data kevalidan didapat dari lembar angket penilaian ahli materi dan ahli media. Proses analisis data kevalidan dilakukan dengan langkah-langlah yaitu: (1) menghitung skor total yang diperoleh; (2) menghitung ratarata penilaian masing-masing ahli dengan skor total dibagi banyaknya butir; (3) mengkonversi skor rata-rata tiap ahli menjadi data kualitatif sesuai Tabel 1 dengan skor maksimal ideal 4 dan skor minimal ideal 1 , sehingga diperoleh rentang skor pada Tabel 2. Modul matematika dengan model pembelajaran berbasis masalah dikatakan valid jika rata-rata penilaian ahli materi dan ahli media minimal dalam kriteria "baik".

Tabel 2. Konversi Data Mengukur Kevalidan

\begin{tabular}{ll}
\hline Rentang Skor & Kriteria \\
\hline$X>3,40$ & Sangat Baik \\
$2,80<X \leq 3,40$ & Baik \\
$2,20<X \leq 2,80$ & Cukup \\
$1,60<X \leq 2,20$ & Kurang \\
$X \leq 1,60$ & Sangat Kurang \\
\hline
\end{tabular}

Analisis kepraktisan didapat dari data hasil angket respon siswa dan lembar observasi keterlaksanaan pembelajaran. Proses analisis hasil angket respon siswa dilakukan sama dengan langkah-langkah analisis kevalidan. Adapun, analisis data lembar observasi keterlaksanaan pembelajaran dilakukan dengan langkah-langkah yaitu: (1) memberikan skor 1 untuk pilihan "Ya" dan 0 untuk pilihan "Tidak"; (2) menghitung persentase keterlaksanaan pembelajaran yaitu banyak skor jawaban "Ya" dibagi banyaknya butir pernyataan dikali seratus; dan (3) mengkonversi hasil persentase keterlaksanaan pembelajaran menjadi data kualitatif dengan mangacu pada kriteria pada Tabel 3 yang dikemukakan Arikunto (2013, p.281). Modul matematika dengan model pembelajaran berbasis masalah dikatakan praktis jika kriteria hasil angket respon siswa dan kriteria hasil observasi keterlaksanaan pembelajaran minimal dalam kriteria "baik".

Tabel 3. Kriteria Penilaian Keterlaksanaan Pembelajaran

\begin{tabular}{ll}
\hline Rentang Skor & Kriteria \\
\hline $80-100$ & Sangat Baik \\
$66-79$ & Baik \\
$56-65$ & Cukup \\
$40-55$ & Kurang \\
$30-39$ & Sangat Kurang \\
\hline
\end{tabular}

Analisis keefektifan diperoleh dari hasil tes belajar siswa. Pengolahan skor hasil tes belajar siswa berdasarkan Penilain Acuan Patokan (PAP) yaitu, pengolahan skor dilakukan dengan mengacu atau mendasarkan pada kriterium atau criterion (patokan) (Sudijono, 2007, p.312). Kriteria pada penelitian ini berdasarkan Kriteria Ketuntasan Minimal (KKM) yang tetapkan oleh sekolah yaitu 71. Analisis data hasil tes dilakukan dengan langkah-langkah yaitu: (1) menghitung banyaknya siswa yang tuntas KKM; (2) menghitung persetase ketuntasan klasikal yaitu banyaknya 
siswa yang tuntas KKM dibagi dengan banyak siswa yang mengikuti tes dikali seratus; dan (3) mengkonversi persentase ketuntasan klasikal sesuai Tabel 1 dengan skor maksimal 100 dan skor minimal 0 , sehingga diperoleh rentang skor pada Tabel 4 . Modul matematika dengan model pembelajaran berbasis masalah dikatakan efektifjika persentase ketuntasan klasikal minimal berada pada kriteria "baik".

Tabel 4. Konversi Data Mengukur Keefektifan

\begin{tabular}{ll}
\hline Rentang Skor & Kriteria \\
\hline$X>79,988$ & Sangat Baik \\
$59,996<X \leq 79,988$ & Baik \\
$40,004<X \leq 59,996$ & Cukup \\
$20,012<X \leq 40,004$ & Kurang \\
$X \leq 20,012$ & Sangat Kurang \\
\hline
\end{tabular}

HASIL DAN PEMBAHASAN

Penelitian ini menghasilkan suatu produk berupa modul matematika dengan model pembelajaran berbasis masalah untuk siswa kelas VII SMP. Materi yang disusun dalam modul yaitu tentang materi segiempat. Modul yang dikembangkan disusun berdasarkan karakteristik model pembelajaran berbasis masalah, yaitu memuat masalah kontekstual sebagai awal proses pembelajaran. Selain itu, alur penyajian materi dalam modul juga disesuaikan dengan sintaks pembelajaran berbasis masalah yaitu mengorientasi siswa pada masalah, mengorganisasi siswa untuk belajar, memandu siswa untuk melakukan investigasi baik secara individu maupun kelompok, mengembangkan dan menyajikan prosedur pemecahan masalah, dan menganalisis dan mengevaluasi proses pemecahan masalah.

Prosedur pengembangan modul ini menggunakan model pengembangan ADDIE yang dikemukakan oleh Dick dan Carry antara lain Analysis, Design, Development, Implementation, Evaluation. Melalui tahapan tersebut, peneliti dapat mengetahui kualitas modul yang dikembangkan. Penilaian modul yang dikembangkan diperoleh dari ahli materi dan ahli media. Ahli materi penilaian modul ini adalah dosen dari Program Studi Pendidikan Matematika FKIP Universitas PGRI Yogyakarta dan guru matematika SMP Negeri 2 Pajangan. Data hasil penilaian dosen ahli materi disajikan pada Tabel 5.

Tabel 5. Hasil Penilain Dosen Ahli Materi

\begin{tabular}{lll}
\hline Aspek & Rata-rata & Kriteria \\
\hline Kelayakan isi & 3,44 & Baik \\
$\begin{array}{l}\text { Penyajian } \\
\text { Keterpaduan dengan pembelajaran } \\
\text { berbasis masalah }\end{array}$ & 3,45 & Baik \\
$\begin{array}{l}\text { Skor Total } \\
\text { Rata-rata Total }\end{array}$ & Baik \\
\hline
\end{tabular}

Berdasarkan Tabel 5 dapat dilihat bahwa dari penilaian dosen ahli materi diperoleh skor rata-rata total 3,36 dengan kriteria kualitatif "baik". Sedangkan hasil angket penilaian guru ahli materi disajikan pada Tabel 6.

Tabel 6. Hasil Penilain Guru Ahli Materi

\begin{tabular}{lll}
\hline Aspek & Rata-rata & Kriteria \\
\hline Kelayakan isi & 2,94 & Baik \\
Penyajian & 2,91 & Baik \\
Keterpaduan dengan pembelajaran & 2,80 & Cukup \\
berbasis masalah & & \\
Skor Total & 8,65 & \\
Rata-rata Total & 2,88 & Baik \\
\hline
\end{tabular}

Berdasarkan Tabel 6 dapat dilihat bahwa dari penilaian guru ahli materi diperoleh skor rata-rata total 2,88 dengan kriteria kualitatif "baik". 
Ahli media yang menilai modul ini adalah satu orang dosen dari Program Studi Pendidikan Matematika FKIP Universitas PGRI Yogyakarta. Data hasil angket penilaian ahli media disajikan pada Tabel 7.

Tabel 7. Hasil Penilaian Ahli Media

\begin{tabular}{lll}
\hline Aspek & Rata-rata & Kriteria \\
\hline Tampilan & 3,17 & Baik \\
Bahasa & 3,00 & Baik \\
Skor Total & 6,17 & \\
Rata-rata Total & 3,08 & Baik \\
\hline
\end{tabular}

Berdasarkan Tabel 7, dapat dilihat bahwa skor rata-rata total penilaian ahli media yaitu 3,08, sehingga hasil penilaian ahli media termasuk dalam kriteria "baik".

Berdasarkan penilaian yang diperoleh dari ahli materi dan ahli media yang telah memenuhi kriteria minimal "baik", maka dapat disimpulkan bahwa modul matematika dengan model pembelajaran berbasis masalah untuk siswa kelas VII SMP pada materi segiempat memenuhi kriteria valid. Selain itu, modul yang dikembangkan juga direvisi berdasarkan masukan dari masing-masing ahli materi dan ahli media, sehingga layak untuk diujicobakan.

Uji coba dilaksanakan di kelas VII A SMP Negeri 2 Pajangan yang terdiri dari 32 siswa. Uji coba penelitian dilaksanakan sebayak 5 kali pertemuan dengan rincian 4 kali pertemuan untuk kegiatan pembelajaran dan 1 kali pertemuan untuk tes dan pengisian angket respon siswa. Saat melakukan uji coba, peneliti mengajak observer untuk mengamati keterlaksanaan pembelajaran dan mencatatnya pada lembar observasi yang telah dirancang. Data yang diperoleh dari hasil uji coba pembelajaran menggunakan modul antara lain data hasil angket respon siswa, data tes hasil belajar siswa, dan data lembar observasi keterlaksanaan pembelajaran. Data hasil angket respon siswa dan hasil lembar observasi keterlaksanaan pembelajaran digunakan untuk mengukur kepraktisan modul yang dikembangkan. Sedangkan data tes hasil belajar digunakan untuk mengukur keefektifan modul yang dikembangkan.

Data hasil angket respon siswa meliputi aspek tampilan, aspek penyajian, dan aspek manfaat. Rekapitulasi data hasil angket respon siswa disajiakn dalam Tabel 8.

Tabel 8. Hasil Angket Respon Siswa

\begin{tabular}{lll}
\hline Aspek & Rata-rata & Kriteria \\
\hline Tampilan & 3,11 & Baik \\
Penyajian & 3,12 & Baik \\
Manfaat & 3,14 & Baik \\
Skor Total & 9,37 & \\
Rata-rata Total & 3,12 & Baik \\
\hline
\end{tabular}

Berdasarkan data hasil angket respon siswa pada Tabel 8 diperoleh rata-rata total 3,12 yang termasuk pada kriteria "baik". Sedangkan data persentase keterlaksanaan pembelajaran kegiatan guru dan kegiatan siswa disajikan pada Tabel 9.

Tabel 9. Hasil Observasi Keterlaksanaan Pembelajaran

\begin{tabular}{lccccc}
\hline & \multicolumn{3}{c}{ Persentase Keterlaksanaan Pembelajaran Tiap Pertemuan } & \multirow{2}{*}{ Rata-rata } \\
\cline { 2 - 5 } & 1 & 2 & 3 & 4 & \\
\hline Guru & 100 & 81,82 & 90,91 & 90,91 & 90,91 \\
Siswa & 100 & 81,82 & 81,82 & 90,91 & 88,64 \\
& \multicolumn{4}{c}{ Rata-rata total } \\
\hline
\end{tabular}

Data persentase keterlaksanaan pembelajaran pada Tabel 9 menunjukkan bahwa rata-rata persentase keterlaksanaan kegiatan guru adalah 90,91 termasuk dalam kriteria "sangat baik" dan rata-rata persentase keterlaksanaan kegiatan siswa adalah 88,64 termasuk dalam kriteria "sangat baik". Dengan demikian, secara keseluruhan rata-rata total persentase keterlaksanaan kegiatan guru dan siswa adalah 89,78. Berdasarkan data hasil angket respon siswa dan hasil observasi keterlaksanaan pembelajaran yang telah memenuhi kriteria minimal 
"baik", maka dapat disimpulkan modul matematika dengan model pembelajaran berbasis masalah untuk siswa kelas VII SMP pada materi segiempat memenuhi kriteria praktis.

Data tes hasil belajar digunakan untuk mengukur keefektifan modul yang dikembangkan. Tes hasil belajar dilakukan pada akhir pertemuan kegiatan uji coba. Dari hasil analisis terdapat 22 siswa yang tuntas dari 30 siswa yang mengikuti tes ( 2 siswa tidak hadir), sehingga persentase ketuntasan yang diperoleh yaitu $73,33 \%$. Persentase ketuntasan klasikal yang dicapai sebesar 73,33\% termasuk dalam kriteria "baik" seperti pada Tabel 4. Dengan demikian dapat disimpulkan bahwa modul matematika dengan model pembelajaran berbasis masalah untuksiswa kelas VII SMP pada materi segiempat memenuhi kriteria efektif.

\section{Pembahasan}

Hasil penelitian menunjaukkan bahwa modul pembelajaran matematika dengan model pembelajaran berbasis masalah yang dikembangkan memenuhi kriteria valid, praktis, dan efektif, sehingga layak digunakan dalam pembelajaran matematika. Temuan penelitian ini tentunya sejalan dengan penelitian-penelitian yang telah dilakukan sebelumnya (misalnya Bukhori, 2018; Cahyono, 2017; Masitoh \& Hartono, 2017; Riadi \& Retnawati, 2014; Susanto \& Retnawati, 2016). Modul matematika yang dihasilkan dalam penelitian ini diharapkan dapat memperkaya bahan ajar bagi guru matematika, terutama dalam rangka meningkatkan partisipasi aktif siswa dalam pembelajaran matematika.

Temuan penelitian juga menunjukkan bahwa modul matematika dengan pembelajaran berbasis masalah efektif ditinjau dari prestasi belajar siswa pada materi segiempat. Hal tersebut tidak terlepas dari adanya aktivitasaktivitas yang mampu meningkatkan peran aktif siswa melalui langkah-langkah pembelajaran berbasis masalah. Hal tersebut tentunya sesuai dengan hasil-hasil penelitian sebelumnya (misalnya Bukhori, 2018; Jailani et al., 2017; Susanto \& Retnawati, 2016). Mencermati temuan penelitian ini dan hasil-hasil penelitian para ahli sebelumnya, maka pembelajaran berbasis masalah dapat dijadikan sebagai salah satu alternatif untuk meningkatkan hasil belajar matematika siswa.

Efektifnya modul yang dikembangkan juga tidak terlepas karena adanya penyajian masalah sebagai titik awal pembelajaran sampai dengan mengevaluasi hasil pemecahan masalah. Secara lebih rinci tahapan model pembelajaran berbasis masalah yang meliputi: 1) orientasi siswa pada masalah, 2) mengorganisasikan siswa untuk belajar, 3) membimbing penyelidikan secara mandiri atau kelompok, 4) mengembangkan dan menyajikan hasil karya, dan 5) menganalisis dan mengevaluasi hasil pemecahan masalah (Putra, 2013, p.78). Pada tahapan pembelajaran tersebut terdapat kegiatan untuk melakukan penyelidikan melalui diskusi kelompok. Dengan adanya diskusi kelompok, siswa akan berdiskusi dengan anggota kelompok untuk menemukan solusi dan memecahkan permasalahan yang disajikan pada modul. Hal tersebut tentunya membantu siswa untuk memahami dan menyelesaikan masalah-masalah yang diberikan dalam modul.

Saat berdiskusi siswa juga dapat saling bertukar pikiran, bertanya, menjawab, dan mengkoreksi setiap konsep yang muncul pada permasalahan yang diberikan. Dengan adanya diskusi kelompok siswa menjadi lebih aktif dalam proses pembelajaran, sehingga proses belajar menjadi bermakna dan dapat meningkatkan hasil belajar siswa. Hal ini sejalan dengan hasil penelitian Pratama (2016) yang menunjukkan bahwa modul dengan model pembelajaran berbasis masalah efektif berdasarkan persentase ketuntasan belajar siswa, karena dalam aktivitas pembelajaran masing-masing siswa termotivasi untuk berperan aktif, terutama ketika berdiskusi kelompok untuk memecahkan masalah yang diberikan.

Berdasarkan uraian pembahasan yang telah dikemukan, dapat disimpulkan bahwa modul matematika dengan model pembelajaran berbasis masalah untuk siswa kelas VII SMP pada materi segiempat telah memenuhi kriteria valid, praktis, dan efektif, sehingga layak untuk digunakan dalam kegiatan pembelajaran. Namun, dalam proses pengembangan modul tersebut masih terdapat beberapa keterbatasan, diantaranya subjek yang terlibat dalam proses uji coba masih sangat terbatas, sehingga kualitas produk yang dikembangkan perlu diuji kembali. Sebagai implikasi dari hasil penelitian ini, tentunya diharapkan agar kedepannya modul yang dikembangkan ini dapat diimplementasikan pada skala yang lebih luas.

\section{SIMPULAN}

Berdasarkan hasil penelitian dan pembahasan terhadap modul yang dikembangkan, maka dapat disimpulkan beberapa hal. Pertama, modul matematika dengan pembelajaran berbasis masalah valid ditinjau dari hasil penilaian oleh ahli materi dan ahli media. Penilaian dosen ahli materi diperoleh skor rata-rata 3,36 serta penilaian 
guru ahli materi diperoleh skor rata-rata 2,88 dengan keduanya memenuhi kriteria "baik". Penilaian ahli media memperoleh skor rata-rata 3,08 dengan kriteria "baik". Kedua, modul matematika dengan pembelajaran berbasis masalah praktis ditinjau dari hasil angket respon siswa dan hasil observasi keterlaksanaan pembelajaran. Hasil angket respon siswa secara keseluruhan mendapatkan skor rata-rata 3,12 dengan kriteria "baik" dan hasil observasi keterlaksanaan diperoleh skor rata-rata 89,78 dengan kriteria "sangat baik". Ketiga, modul matematika dengan pembelajaran berbasis masalah efektif ditinjau dari nilai tes hasil belajar siswa. Persentase ketuntasasan tes hasil belajar siswa yaitu 73,33\%, dengan kriteria "baik".

Penelitian dan pengembangan ini masih memiliki keterbatasan, yaitu subjek yang terlibat dalam proses uji coba produk hanya satu kelas dari satu sekolah saja. Untuk itu hasil penelitian ini masih perlu ditindaklanjuti dengan melakukan implementasi pada skala yang lebih luas. Selain itu, disarankan juga bagi peneliti lain untuk melakukan penelitian dan pengembangan modul serupa pada materi-materi lainnya, baik pada jenjang SMP maupun SMA. Hasil penelitian ini juga diharapkan dapat dijadikan sebagai salah satu bahan ajar bagi guru matematika SMP, terutama untuk mengajarkan materi segiempat. Dengan adanya penelitian dan pengembangan ini diharapkan dapat menginspirasi dan memotivasi guru-guru di Indonesia untuk mengembangkan modul-modul pembelajaran lainnya.

\section{DAFTAR PUSTAKA}

Apino, E., \& Retnawati, H. (2017). Developing instructional design to improve mathematical higher order thinking skills of students. Journal of Physics: Conference Series, 812(1). 1-7. doi: https://doi.org/10.1088/17426596/812/1/012100

Arends, R. I. (2007). Lerning to teach. New York, NY: Mc Graw Hill Companies.

Arikunto, S. (2013). Dasar-dasar evaluasi pendidikan. Jakarta: Bumi Askara.

Bukhori, B. (2018). Pengembangan perangkat pembelajaran dengan pendekatan PBL berorientasi pada penalaran matematis dan rasa ingin tahu. Pythagoras: Jurnal Pendidikan Matematika, 13(2), 133-147. doi: https://doi.org/10.21831/pg.v13i2.21169

Cahyono, A. E. Y. (2017). Pengembangan perangkat pembelajaran dengan model PBL berorientasi pada kemampuan berpikir kreatif dan inisiatif siswa. Pythagoras: Jurnal Pendidikan Matematika, 12(1), 1-11. doi: https://doi.org/10.21831/pg.v12i1.14052

Csíkos, C., Szitányi, J., \& Kelemen, R. (2011). The effects of using drawings in developing young children's mathematical word problem solving: A design experiment with third-grade Hungarian students. Educational Studies in Mathematics, 81(1), 47-65. doi: https://doi.org/10.1007/s10649-011-9360-z

Depdiknas. (2008). Panduan pengembangan bahan ajar. Jakarta: Author.

Firdaus, F., Kailani, I., Bakar, M. N. B., \& Bakry, B. (2015). Developing critical thinking skills of students in mathematics learning. Journal of Education and Learning (EduLearn), 9(3), 226-236. doi: http://dx.doi.org/10.11591/edulearn.v9i3.1830

Fitrianawati, M., \& Hartono, H. (2016). Perbandingan keefektifan PBL berseting TGT dan GI ditinjau dari prestasi belajar, kemampuan berpikir kreatif dan toleransi. Jurnal Riset Pendidikan Matematika, 3(1), 55-65. doi: https://doi.org/10.21831/jrpm.v3i1.9684

Gazali, R. (2016). Pengembangan bahan ajar matematika untuk siswa SMP berdasarkan teori belajar Ausubel. Pythagoras: Jurnal Pendidikan Matematika, 11(2), 182-192. doi: https://doi.org/10.21831/pg.v11i2.10644

Hmelo-Silver, C. E. (2004). Problem-based learning: What and how do students learn. Educational Psychology Review, 16(3), 235-266. doi: https://doi.org/10.1023/B:EDPR.0000034022.16470.f3

Jailani, J., Sugiman, S., \& Apino, E. (2017). Implementing the problem-based learning in order to improve the students' HOTS and characters. Jurnal Riset Pendidikan Matematika, 4(2), 247-259. doi: https://doi.org/10.21831/jrpm.v4i2.17674 
Masitoh, L. F., \& Hartono, H. (2017). Pengembangan perangkat pembelajaran matematika dengan pendekatan PBL berorientasi pada kemampuan berpikir kreatif dan self-efficacy. Pythagoras: Jurnal Pendidikan Matematika, 12(2), 220-230. doi: https://doi.org/10.21831/pg.v12i2.15769

Mulyatiningsih, E. (2012). Riset terapan bidang pendidikan dan teknik. Yogyakarta: UNY Press.

NCTM. (2000). Principles and standards for school mathematics. Reston, VA: Author

Özreçberoğlu, N., \& Çağanağa, C. K. (2017). Making it count: Strategies for improving problem-solving skills in mathematics for students and teachers' classroom management. EURASIA Journal of Mathematics, Science and Technology Education, 14(4), 1253-1261. doi: https://doi.org/10.29333/ejmste/82536

Pajares, M. F. (1992). Teachers' beliefs and educational research: Cleaning up a messy consruct. Review of Educational Research, 62(3), 307-332. doi: https://doi.org/10.3102/00346543062003307

Pangesti, F, T. P., \& Retnowati, E. (2017). Pengembangan bahan ajar geometri SMP berbasis cognitive load theory berorientasi pada prestasi belajar siswa. Pythagoras: Jurnal Pendidikan Matematika, 12(1), 33-46. doi: https://doi.org/10.21831/pg.v12i1.14055

Pratama, D. (2016). Pengembangan modul matematika untuk pembelajaran berbasis masalah (problem based learning) pada materi pokok himpunan kelas VII SMP (Skripsi tidak diterbitkan, Universitas Sebelas Maret, Surakarta).

Putra, S. R. (2013). Desain belajar mengajar kreatif berbasis sains. Yogyakarta: DIVA Press.

Riadi, A., \& Retnawati, H. (2014). Pengembangan perangkat pembelajaran untuk meningkatkan HOTS pada kompetensi bangun ruang sisi datar. Pythagoras: Jurnal Pendidikan Matematika, 9(2), 126-135. doi: https://doi.org/10.21831/pg.v9i2.9074

Rochmad, R. (2012). Desain model pengembangan perangkat pembelajaran matematika. Kreano, Jurnal Matematika Kreatif-Inovatif, 3(1), 59-72. doi: https://doi.org/10.15294/kreano.v3i1.2613

Rusman, R. (2014). Model-model pembelajaran mengembangkan profesionalisme guru. Jakarta: Rajawali Pers.

Rhosyida, N., \& Jailani, J. (2014). Pengembangan modul matematika smk bidang seni, kerajinan, dan pariwisata berbasis open-ended problem sebagai implementasi KTSP. Jurnal Riset Pendidikan Matematika, 1(1), 35-47. doi: https://doi.org/10.21831/jrpm.v1i1.2662

Sanders, S. (2016). Critical and creative thinkers in mathematics classrooms. Journal of Student Engagement: Education Matters, 6(1), 19-27. Retrieved from http://ro.uow.edu.au/jseem/vol6/iss1/4

Sudijono, A. (2007). Pengantar evaluasi pendidikan. Jakarta: PT Raja Grafindo Persada.

Sugiyono, S. (2015). Metode penelitian dan pengembangan research and development. Bandung: Alfabeta.

Sukiman, S. (2012). Pengembangan media pembelajaran. Yogyakarta: Pedagogia.

Sulistyani, N., \& Retnawati, H. (2015). Pengembangan perangkat pembelajaran bangun ruang di SMP dengan pendekatan problem-based learning. Jurnal Riset Pendidikan Matematika, 2(2), 197 - 210. doi: https://doi.org/10.21831/jrpm.v2i2.7334

Sungur, S., \& Tekkaya, C. (2006). Effects of problem-based learning and traditional instruction on self-regulated learning. The Journal of Educational Research, 99(5), 307-320. doi: https://doi.org/10.3200/JOER.-99.5.307320

Susanto, E., \& Retnawati, H. (2016). Perangkat pembelajaran matematika bercirikan PBL untuk mengembangkan HOTS siswa SMA. Jurnal Riset Pendidikan Matematika, 3(2), 189-197. doi: https://doi.org/10.21831/jrpm.v3i2.10631

Trisnadati, I. (2018). Komparasi pendekatan matematika realistik dengan model PBL dan PjBL ditinjau dari kemampuan interpersonal, berfikir kritis, dan prestasi belajar. Pythagoras: Jurnal Pendidikan Matematika, 13(1), 99-109. doi: https://doi.org/10.21831/pg.v13i1.21219 
Tłuściak-Deliowska, A. (2017). Unity of purpose is not enough? The importance of teachers collaboration in school: Some reflections based on a case study. Journal of Modern Science, 32(1), 45-62. Retrieved from http://cejsh.icm.edu.pl/cejsh/element/bwmeta1.element.desklight-8d60ee46-d807-4edd-9adf5bd6f25a67e9/c/45_pdfsam_kwartalnik_1_32_2017_5.05.pdf

Widoyoko, E. P. (2009). Evaluasi program pembelajaran. Yogyakarta: Pustaka Pelajar. 